\title{
KAJIAN TERHADAP RASM \\ DALAM NASKAH MUSHAF AL-QUR`AN MADURA
}

\author{
Luluk Asfiatur Rohmah \\ PP. Salafiyah Sukorejo Bangil Pasuruan \\ luviaizumi@gmail.com
}

\begin{abstract}
Muslim's approach to the holy book al-Qur 'an is expressed in various activities, reading, memorizing, writing, transcribing, and others. The copying of Al-Qur 'an has been being strictly controlled by the rasm used, rasm uthmani and rasm imla'i, and the copies has been being maintained by the museum, pesantren, collectors, heirs and others with various purposes and interests. This paper examines the manuscripts of the Mushaf al-Qur 'an H. Habibullah from Konang Village, Bangkalan, Madura from the aspect of using rasm, vowels and punctuation. The result of this study is that the copying of the manuscripts of the Mushaf al-Qur'an H. Habibullah is inconsistent in applying the rules for writing rasm uthmānī and rasm imlā'i from the rules for discarding letters, adding letters, writing hamzah, changing letters and writing punctuation (harakat). The writing of this Mushaf manuscript also came out of the corridors of the rules for writing rasm uthmānī and rasm imlā'i. This inconsistency was influenced by the absence of a reference basis for writing the Mushaf at that time, as well as the unfamiliarity of Nusantara Muslims with the Arabic language rules, nahw-ṣarf.
\end{abstract}

Keywords: Consistency, Manuscripts of the Al-Qur 'an, Madura, Rasm

\begin{abstract}
Abstrak
Pendekatan umat muslim atas kitab sucinya al-Qur’an diekspresikan dalam beragam kegiatan, membaca, menghafal, menulis/menyalin, dan lainnya. Penyalinan al-Qur`an akan dikontrol tegas oleh rasm yang digunakan, rasm uthmani dan rasm imla'i, dan hasil salinan akan dipelihara oleh musium, pesantren, kolektor, ahli waris dan lainnya dengan beragam tujuan dan kepentingan. Tulisan ini mengkaji naskah Mushaf al-Qur`an H. Habibullah dari Desa Konang, Bangkalan, Madura dari aspek penggunaan rasm, harakat dan tanda baca. Hasil dari kajian ini ialah penyalinan naskah Mushaf al-Qur`an H. Habibullah tidak konsisten dalam menerapkan aturan penulisan rasm uthmānì dan rasm imlā' $i$ dari kaidah-kaidah pembuangan huruf, penambahan huruf, penulisan hamzah, penggantian huruf dan penulisan tanda baca (harakat), penulisan naskah mushaf ini juga ada beberapa yang keluar dari koridor kaidah penulisan rasm uthmānn̄ dan rasm imlā'i. Inkonsistensi ini dipengaruhi oleh tidak adanya dasar acuan penulisan mushaf pada masa itu, serta tidak akrabnya muslim Nusantara dengan kaidah bahasa Arab, nahw-șarf.
\end{abstract}

Kata Kunci: Konsistensi,Naskah Mushaf al-Qur`an,Madura,Rasm 


\section{A. Pendahuluan}

Kegiatan penyalinan Al-Qur`anterus telah berlangsung sejak al-Qur`an diturunkan hingga saat ini. Sepanjang sejarahnya, pengajaran Al-Qur`anberjalan berdampingan dengan penulisannya. Penulisan Al-Qur`antidak hanya untuk kebutuhan pengajaran, tetapi juga bertujuan untuk memelihara teks yang benar dan sebagai alat kontrol terhadap penyimpanganpenyimpangan. ${ }^{1}$

Penyalinan al-Qur`anbermula dari pengajaran baca tulis Arab yang dilakukan di sekolah tradisional ataupun keluarga. Penulisan (baca: penyalinan) al-Qur`andi Indonesia mayoritas disponsori oleh tiga pihak utama yakni, kerajaan, kaum elite sosial, dan pesantren dengan beragam tujuan dan motif penyalinan. Naskah-naskah produk salinan nantinya dikoleksi oleh perpustakaan, museum, pesantren, kolektor, dan ahli waris.Salah satunya seperti naskah Mushaf al-Qur`an H. Habibullah yang disimpan oleh ahli waris di desa Konang, Bangkalan, Madura setelah dimanfaatkan sebagai media belajar al-Qur'an.

Aspek lain yang mengontrol laju gerak penyalinan mushaf ialah rasm, sebuah panduan dalam penulisan huruf-huruf arab. Pemilihan rasm dalam penulisan al-Qur`andibedakan antara rasm uthmani dan rasm imla 'i.Penggunaan tanda baca juga ikut menyumbang peran di dalamnya.Dalam tulisan ini dikaji penggunakan rasm dan rasm serta dabt dalam penyalinan mushaf H. Habibullah.

Kajian ini bersifat deskriptif-analisis, yakni mendeskripsikan berbagai aspek dari naskah Mushaf al-Qur`an H. Habibullah, seperti kondisi naskah, sejarah penyalinan, dilanjutkan dengan analisis aspek rasm penulisannya. Disisi lain kajian ini menarik untuk diteliti karena sebelumnya belum pernah ditemukan kajian yang membahas terkait naskah Mushaf al-Qur`an H. Habibullah.

\section{B. Ilmu Rasm dan Signifikasinya pada Penulisan Mushaf al-Qur'an}

Kata Rasm merupakan bentuk maṣdar dari fi'ilmạḍ̂̄ رسم-يرسم(rasama-yarsumu) mempunyai beberapa makna, yaitu al-tașawwur (penggambaran, ilustrasi), al-șurah (sketsa, gambar), yaitu al-athar (bekas, jejak),al-wașfu (pensifatan, uraian, penjelasan, pelukisan), alsya'īratu wa al-țafsu (upacara), al- 'ādatu al-rasmiyyatu (tata cara, formalitas), athāru al-dār

\footnotetext{
${ }^{1}$ Rif'atun Najikhah, "Mushaf Menara Kudus Cetakan 1974", (Skipsi di Sekolah Tinggi Agama Islam al-Anwar, Rembang, 2018), hlm. 2.
} 
Kajian Terhadap Rasm dalam Naskah Mushaf ..... Luluk Asfiatur Rohmah

Doi: doi.org/10.47454/itqan.v4i2.683

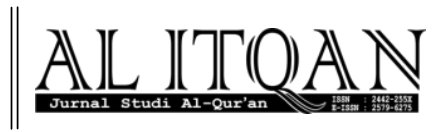

al-lașiqatu bi al-arḍi (bekas-bekas rumah pada tanah), al-'alāmah (alamat, tanda), al-amru (perintah), al-maksu (pajak, bea), al-majmalī (skets, rencana kasar, garis-garis besar), alnażriyyu (lukisan bebas (memakai tangan tanpa mistar). ${ }^{2}$

Secara spesifik, rasm sendiri mempunyai arti al-athar yang bermakna bekas atau peninggalan. ${ }^{3}$ Kata lain yang sama artinya adalah الخطّ، الكتابة، الرقم، الزبر، السطر ، الرشم kesemuanya mempunyai arti tulisan. Maka rasm dengan segala persamaannya mempunyai arti bekas tulisan. ${ }^{4}$ Maksudnya adalah seorang penulis yang telah menggoreskan penanya, maka ia akan meninggalkan bekas pada tulisannya. ${ }^{5}$

Ilmu rasm merupakan ilmu untuk mengetahui perbedaan rasm mushaf Uthmānī atas kaidah-kaidah rasmqiyās̄̄ dari segi ḥadhf, ziyādah, badal, faṣl dan waṣl, dan sebagainya. ${ }^{6}$ Dalam penulisan dan penyalinan al-Qur`an dikenal dua istilah rasam, rasm qiyāsì/rasm imlāi dan rasmIștilāḥ̂̄/rasm Uthmānī. Dua rasm ini yang mengawal penyalinan al-Qur’an sejak awal diwahyukan hingga sekarang di seluruh penjuru dunia.

Istilah rasm mulai digunakan secara merata pada abad terakhir sebagai bentuk pengetahuan tentang penulisan mushaf. Hal tersebut terlihat dalam kitab-kitab karangan yang memuat pembahasan mengenai disiplin ilmu ini.Ketika istilah rasm telah menjadi nama disiplin ilmu penulisan mushaf, maka istilah ini digunakan juga untuk menunjukkan kaidah penulisan yang sudah ditetapkan para Ulama. ${ }^{7}$ Ulama membagi rasm menjadi dua bagian: pertama, Rasm qiyāsī atau yang biasa disebut dengan rasm imlāi adalah salah satu rasm yang sesuai antara penulisan dengan pelafalannya. Kemudian para ulama ahli bahasa arab menjelaskan kaidah-kaidahnya. ${ }^{8}$ Kedua, RasmIștilāḥ̄ atau yang dikenal dengan rasm Uthmānī adalah pola penulisan kalimat-kalimat al-Qur`anyang telah disetujui oleh sahabat 'Uthmān bin

\footnotetext{
${ }^{2}$ Ahmad Warson Munawwir, Al-Munawwir Kamus Arab-Indonesia (Surabaya: Pustaka Progresif, 1997), hlm. 497.

3،Abdul Fattāh Ismā'īl Shalbiy, Rasm al-Mușhaf al-Uthman̄̄ wa Auhāmu al-Mustashriqīn fì qirā'āt al-Qur'ān al-Karīm (t.tp: Maktabah Wahbah, t.th), hlm. 5. Lihat juga Ghānim Qaddūrī al-Hamd, al-Muyassar fì Ilm alRasm al-Muṣhaf wa Dabțihi (Jeddah: Markaz al-Dirāsāt wa al-Ma'lūmāt al-Qur'āniyyāt fī Ma'had al-Imām alShāṭib̄yy, 2016), hlm. 26. Abu 'Amr 'Uthmān bin Sa'īd al-Dāni, al-Muqni' fì Ma'rifati Marsūm Mașāhif Ahli alAmșār (Riyaḍ: Dār al-Tadmuriyyah, 2010), hlm. 14.

${ }^{4} \mathrm{Abu}$ 'Amr 'Uthmān bin Sa'̄̄d al-Dāni, al-Muqni' fì Ma'rifati Marsūm Mașāḥif Ahli al-Amṣār (Riyaụ: Dār alTadmuriyyah, 2010), hlm. 14.

${ }^{5}$ Mazmur Sha'roni, Pedoman Umum Penulisan dan Pentashihan Mushaf al-Qur'an Rasm Uthmani(Jakarta: Departemen agama RI: Badan Penelitian dan Pengembangan Agama Puslitbang Lektur, 1998/1999), hlm. 9.

${ }^{6}$ Abū 'Abd Tawwab 'Abd Majīd Rayyash, Adawāt al-Ḍabt al-Qur'ān̄̄ wa Madlūlātuhā, terj. Abu Ya'la Kurnaedi (t.tp: Pustaka Imam Asy-Syafi'i, t.th), hlm. 5.

${ }^{7}$ Ghānim Qaddūrī al-Hamd, al-Muyassar fì Ilm al-Rasm, hlm. 26

${ }^{8}$ Ghānim Qaddūrī al-Ḥamd, Madā Imkāniyyah Tauhìd al-Rasm fì Tabāà ah al-Mașāhif (Turki: Hai'ah Tadqīq alMașahịif wa al-Qirāah, 2017), hlm. 4.
} 
'Affān pada waktu penulisan mushaf. ${ }^{9}$ Dua rasm ini akan jatuh peran secara bergantian dalam penulisan mushaf al-Qur'an.

\section{Kaidah Rasm Uthmān̄}

Rasm Uthmānī mempunyai kaidah-kaidah di dalam penulisannya. Al-Suyūṭi menyebutkan di dalam kitabnya bahwa kaidah rasm Uthmānī dikelompokkan menjadi enam kaidah. ${ }^{10}$ Namun, Ghānim Qaddūri mengelompokkannya menjadi lima kaidah, yaitu:

a. Membuang huruf (Al-Hadhf), yakni adanya suara yang diucapkan atau dilafalkan tidak sesuai dengan tulisannya. Pembuangan huruf pada rasm Uthmānī ada 5, yaitu: pertama, pembuangan alif pada jama' mudhakkar al-sālim, jama' muannath al-sālim, ḍamīr rafa' muttașil, alif tathniyah, nama-nama isim 'ajam yang lebih dari tiga huruf, dan pembuangan alif yang tidak didasarka kaidah. Kedua, pembuangan wāwu ketika ada dua wāwu berkumpul dalam satu kalimat dan wawu yang kedua di sukun dan jatuh setelah harakat dammah. Jika wāwu sebagai ilustrasi hamzah dan setelahnya terdapat wāwu yang lain serta terdapat $w \bar{a} w u$ di akhir fi' 'il, maka $w \bar{a} w u$ tidak ditulis atau dibuang pada empat tempat. Ketiga, pembuangan ya` ditengah kalimat ketika bersama $y \bar{a}{ }^{`}$ lain. Pembuangan huruf $y \bar{a}$ ' disetiap kalimat yang akhirnya terdapat dua huruf $y \bar{a}$, diantaranya yaitu apabila $y \bar{a}$ ' yang kedua berharakat sukun, membuang $y \bar{a}$ ' asli yang berada di akhir beberapa kalimat dan huruf setelah berharakat sukun untuk menjaga gugurnya, membuang $y \bar{a}$ ' yang berada diujung ayat dan berada di 10 tempat, membuang y $\bar{a}^{\prime}$ damīr mutakallim yang muḍof pada isim munādī, membuangpada beberapa kalimat tanpa alasan yang jelas

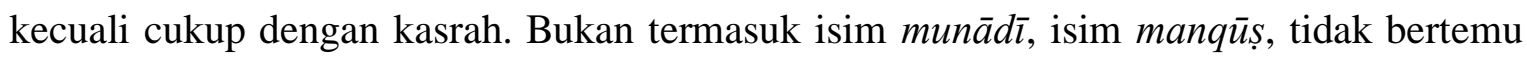
sukun, dan tidak berada di ujung ayat, dan membuang pada beberapa kalimat tanpa alasan yang jelas kecuali cukup dengan kasrah. Bukan termasuk isim munādī, isim manqūṣ, tidak bertemu sukun, dan tidak berada di ujung ayat. Keempat, lam pada semua lafal pada isim mawșull. Kelima, pembuangan nün terdapat pada kalimat di dalam al-Qur’an yang مُسنْلمتِ : (QS. At-Taḥrīm: 5), maka di baca muslimātin (dengan dibaca panjang huruf mimnya).

b. Menambah huruf (Al-Ziyāadah), yakni adanya huruf yang ditulis berbeda dengan pengucapan. Adapun penambahan di dalam tulisan mushaf yaitu terdapat pada huruf alif,

\footnotetext{
${ }^{9}$ Ibid., hlm. 10.

${ }^{10}$ Abd Raḥmān bin Abī Bakr al-Suyūṭī, al-Itqān fì Ulūm al-Qur'ān (Beirut: Dār al-Kutub al-'Ilmiyah, 2018), hlm. 556.

${ }^{11}$ Ghānim Qaddūrī al-Hamd, al-Muyassar fì Ilm al-Rasm, hlm. 105.
} 

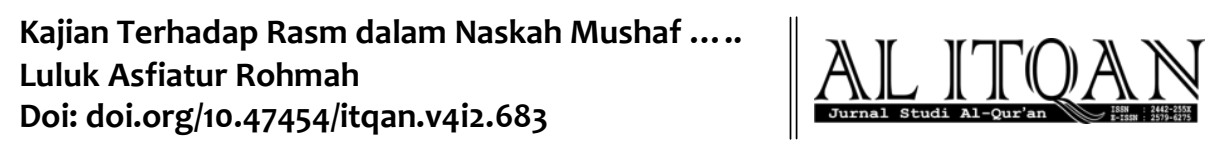

$y \bar{a}{ }^{\prime}$ dan $w \bar{a} w u$, baik penambahannya ditengah kalimat, maupun diakhir kalimat. ${ }^{12}$ Seperti contoh: مِيَائَتَنْنِ dibaca miah dan miatayn (tanpa memanjangkan huruf mimnya).

c. Penulisan hamzah (Al-Hamz), meliputi penulisan hamzah di awal, di tengah, di akhir kalimat. Seperti contoh: شَيْsِ (QS. Al-Baqarah: 20) (hamzah ditulis tanpa huruf tertentu karena hamzah berada di akhir kalimat dan jatuh setelah huruf sukun).

d. Penggantian huruf ( $A l-B a d l)$, yakni mengganti satu huruf ke huruf yang lain, atau menulis suara selain tanda yang terdapat di dalam kitab kaidah bahasa Arab. Huruf-huruf yang terjadi penggantian ( $b a d l$ ) di dalam al-Qur`an adalah huruf alif yang ditulis dengan wāwu di beberapa tempat dan $y \bar{a}$ ' pada tempat yang lain. Begitu juga $t \bar{a}^{\prime}$ ta'nith yang terdapat pada kalimat isim maka ditulis dengan $h \bar{a}$ ', dan $t \bar{a}$ ' pada tempat lain. Seperti contoh, الصََََّّْة,

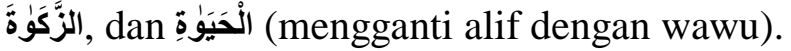

e. Menyambung dan memisah tulisan (Al-Wașl wal-Fașl $)^{13}$, yakni kalimat-kalimat dalam alQur`an terdapat beberapa ditulis secara terpisah dan tersambung dengan yang lainnya. Seperti contoh: kalimat أَنْ لاَ di dalam al-Qur`an penulisannya disambung menjadi أَلَّ.

\section{Kaidah Rasm Imlāi}

Rasm imlāi adalah tata cara penulisan kalimat bahasa Arab yang sesuai dan cocok antara lafal dengan tulisannya. Adapun kaidah-kaidah yang terdapat dalam Rasm imlāi, antara lain :

a. Penulisan hamzah $(\text { al-Hamzah })^{14}$, meliputi penulisan hamzah di awal, di tengah, di akhir kalimat. Seperti contoh: hamzah wașol: أَتُبْ 15, (Hرَأَة (Hamzah di awal kalimat ditulis dengan alif baik itu hamzah wașal atau hamzah qața').

b. Penulisan alif layyinah ${ }^{16}$, meliputi penulisan Alif Layyinah di tengah dan di akhir kalimat. Seperti contoh: الفَتَى , الهُُى (Alif Layyinah yang berada diakhir kalimat maka ditulis dengan huruf $y \bar{a})^{\prime}$.

c. Penambahan huruf (al-hurūf allaty tuzād $)^{17}$ yang terjadi pada huruf alif ketika tengah kalimat pada lafal مائة, baik ketika tunggal maupun tersusun, seperti contoh: خَمسيمِائة dan

\footnotetext{
${ }^{12}$ Ibid., hlm. 125.

${ }^{13}$ Ghānim Qaddūrī al-Hamd, al-Muyassar fì Ilm al-Rasm, hlm. 162-175.

${ }^{14}$ Abd al-Salam Muhammad Hārūn, Qawā 'id al-Imlā' (Kediri: Dār al-Mubtadī̄n, t.th), hlm. 1-10.

${ }^{15}$ Fahmī al-Najār, Qawā'id al-Imlā' fí 'Ashrah Durūs Sahlah (Riyadh: Mazīdah wa Munqiḥah, 1429 H.), hlm. 9.

${ }^{16}$ Abd al-Salām Muhammad Hārūn, Qawa'id al-Imla', hlm. 11-19.

${ }^{17}$ Ibid., hlm. 20-22.
} 
اولئك ,اولاء ,اولى ,اولا، ,اولو: Seperti contoh (penambahan huruf wawu setelah huruf hamzah, khusus pada lafal-lafal tersebut).

d. Pengurangan/pembuangan huruf (al-hurūf allaty tunqaș ${ }^{18}$ yang terjadi pada huruf alif, pembuangan wawu pada kalimat-kalimat dengan tujuan takhfif, contoh: طاؤس ,داود, pembuangan $y \bar{a}$ ' pada isim manqus ${ }^{19}$ yang dima'rifatkan dengan ال dan diwakafkan dengan cara memberi harakat sukun pada huruf sebelum yā'. Contoh: المُنَعَال , الَّاع, dan

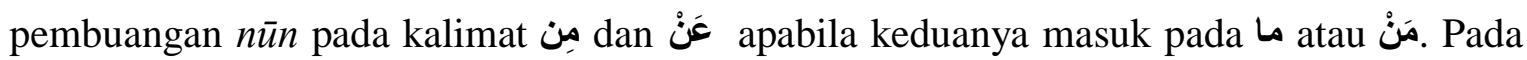

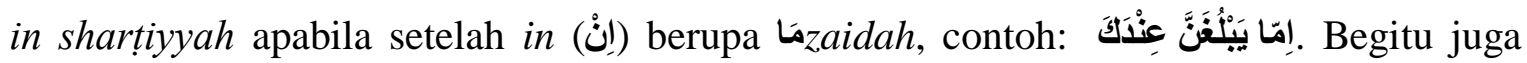
apabila setelahnya berupa

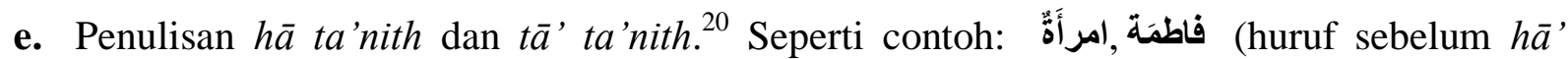
ta'nith itu selalu berharakat fathah). Jika $h \bar{a}$ ' ta'nith diwaqafkan maka diganti dengan $h \bar{a}$ ' dan ditulis marbūtah kecuali apabila dimudhafkan pada isim dhamir. Contoh: امرَأتهُه..21.

f. Menyambung dan memisah kalimat (al-wașl wa al-fașl). Setiap kalimat atau huruf yang bisa dibuat untuk memulai kalam dan mengakhirinya itu harus dipisah (penulisannya) dari lafal sebelum dan sesudahnya. Jika tidak demikian, maka tidak boleh dipisah melainkan harus disambung. Contoh: اين dengan ما masdariyah menjadi اينما. ${ }^{22}$

\section{Dabt dan Kaidah-Kaidah Penulisannya}

Ilmu dabt adalah pemberian tanda-tanda khusus atau simbol-simbol tertentu terhadap huruf untuk membedakannya satu sama lain, seperti pemberian harakat(fathah, dhummah, kasrah), sukun, tanda mād, tanwin, syiddah, ${ }^{23}$ dan cara penulisannya. ${ }^{24}$ Secara garis besar $d a b t$ disebut juga dengan istilah $a l-s h a k l^{25}$ atau al-Naqt. Dabt atau naqt sendiri dibagi menjadi dua

\footnotetext{
${ }^{18}$ Ibid., hlm. 23-33.

${ }^{19}$ Isim yang huruf akhirnya berupa $y \bar{a}$ ' dan sebelumnya berharakat kasrah.

${ }^{20}$ Huruf yang khusus masuk pada kalimat isim dan mencegah isim tersebut menerima tanwin jika bersamaan dengan alamiyah (nama) atau bisa juga disebut huruf yang bisa membedakan antara isim mudzakar dan muannats.

${ }^{21}$ Abd al-Salām Muhammad Hārūn, Qawa 'id al-Imla', hlm. 39-40.

${ }^{22}$ Ibid., hlm. 34 .

${ }^{23}$ Ibrāhim bin Aḥmad bin Sulaiman al-Māraghin̄̄, Dalil al-Hairān 'alā Maurid al-Zam àn (al-Qahirah: Dār alHadīth, t.th), hlm. 345.

${ }^{4}$ Abu Abduttawab Abdul Majid, Ilmu Rasm dan Dhabth: Seluk Beluk Tanda Baca dalam Mushaf alQur'an(t.tp: Pustaka Imam Asy-Syafi'i, 2017), hlm. 6.

${ }^{25}$ Syakl menurut istilah adalah sesuatu yang dapat membedakan huruf dari harakat dan sukun, yakni membedakan apakah huruf tersebut menyandang harakat dhummah, fathah, kasrah maupun sukun, sehingga dapat menghilangkan keserupaan dan kerancuan. Lihat Muḥammad bin Abdillah al-Tanasī, al-Ṭirraz fí Sharḥi Dabț al-Kharrāz (Madīnah: Majma' al-Malik Fahd li Țaba'ah al-Muṣhaf al-Sharīf, 2008), hlm. 35.
} 
Kajian Terhadap Rasm dalam Naskah Mushaf ..... Luluk Asfiatur Rohmah

Doi: doi.org/10.47454/itqan.v4i2.683

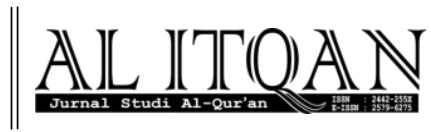

yaitu naqt al-i'rāb (harakat) ${ }^{26}$ dan naqt al-i'jām ${ }^{27}$ (titik pada huruf) ${ }^{28}$.Kaidah dabt i' rābìyang telah dirumuskan, yaitu:

\section{Harakat}

Simbol harakat digambarkan dengan huruf-huruf kecil.Harakat dhummah digambarkan dengan huruf $w \bar{a} w u$ kecil diatas huruf ( $)$, harakat fathah dengan huruf alif kecil yang dibentangkan di atas huruf () dan kasrah dengan $y \bar{a}$ ' dibawah huruf (9) atau lebih mirip dengan alif kecil melintang dibawah huruf. ${ }^{29}$

\section{Sukun}

Sukun itu tidak adanya harakat dan tidak menggambarkan suara tertentudengan kaidah penulisan: Goresan (tarikan) di atas huruf yang disukun menurut madzhab ahli Andalusia, lingkaran kecil diatas huruf seperti angka nol untuk menandakan sukun menurut madzhab Madinah, kepala $k h \bar{a}$ ' tanpa titik (े) diambil dari awal lafal khafif menurut pendapat madzhab ahli Arab seperti imam Khalīl dan Sībawaih, tanda seperti huruf $h \bar{a}$ ' menurut sebagian ahli Arab, dan tanda bulat dan kepala $k h \bar{a}$ ' saja menurut mazhab Abū Dāwud.

\section{Tanwin}

Tanwin adalah nūn mati tambahan yang berada pada akhir isim secara lafal bukan tulisan. Ulama ahli $d a b t$ memiliki beberapa mazhab dalam meletakkan tanda tanwin oleh alFarāhīdī tergantung huruf yang jatuh setelah tanwin, yaitu: Pertama, apabila huruf setelah tanwin berupa huruf halqi, maka tanwin ditulis dua harakat yang tersusun sejajar dan salah satunya berada di atas yang lain. Atau bisa menggunakan satu dhummah dengan topi diatasya.Kedua, jika setelah tanwin berupa huruf $b \bar{a}$ maka tanwin ditulis dengan satu harakat dan menuliskan mim kecil diatas fathah, di depan dhummah, dan dibawah kasrah. Hal ini sebagai tanda bahwa tanwin telah tertukar dengan mim.Ketiga, jika setelah tanwin berupa huruf selain huruf halqī maka tanwin ditulis berdekatan dan tidak sejajar, dengan menjadikan alamat tanwin di depan alamat harakat.

\section{Tasydīd atau Shiddah}

\footnotetext{
${ }^{26}$ Titik yang berfungsi untuk membedakan harakat dalam lafal bahasa Arab. Seperti tanda fathah berada diatas huruf dan kasrah dibawah huruf.

${ }^{27}$ Tanda titik pada huruf yang berfungsi sebagai pembeda jenis huruf atau menjelaskan konsonan suatu huruf, seperti titik satu di bawah huruf $b \bar{a}$,' dua titik di atas huruf $t \bar{a}$ ' dan tiga titik di atas huruf $t h \bar{a}$ '

${ }^{28}$ Sha'bān Muhammad Ismā'il, Rasm al-Mușhaf wa Dabṭhu, hlm. 87. Lihat juga Ghānim Qaddūrī al-Hamd, alMuyassarr fì Ilmi al-Rasm, hlm. 287.

${ }^{29}$ Ghānim Qaddūrī al-Hamd, al-Muyassarr fĩ Ilmi al-Rasm, hlm. 300.
} 
Tasydìd atau shiddah menunjukkan pengulangan dua huruf yang sama jenisnya. Yang pertama disukun yang kedua berharakat. ${ }^{30}$ Penulisannya ada dua bentuk, kepala shin tanpa titik di atas huruf () yang bertashdìd dan menggunakan $d \bar{a} l$.

\section{Mād}

Mayoritas ulama menggunakan tanda mad sebagai tanda bahwa bacaan mad melebihi panjang mad țābi' $\bar{\imath}$ seperti tanda ( ) yang diletakkan sedikit naik.

\section{Hamzah}

Huruf hamzah ditandai dengan dengan huruf 'ain dalam versi kecil, atau huruf 'ain tanpa tubuhnya (є).Hal ini dikarenakan dekatnya makhroj hamzah dengan 'ain.

\section{Naskah Mushaf al-Qur`an Madura}

Naskah al-Qur`an ini awalnya ditulis lengkap 30 juz dengan beberapa juz secara terpisah dan sudah dijilid.Namun sekarang ini, al-Qur`an milik keluarga H. Abdullah Ahmad Syadzili ini hanya ditemukan satu jilid saja, yaitu diawali dengan surat al-Fatihah dan berakhir pada juz kedua ayat 178 surat al-Baqarah. Hal ini dikarenakan mushaf-mushaf lainnya disimpan oleh beberapa ahli waris keluarga yang bertempat tinggal berbeda-beda (di Desa berbeda) dan jika dikonfirmasi kembali.Naskah-naskah tersebut tidak diketahui keberadaannya disebabkan para ahli waris yang menyimpan naskah lainnya sudah meninggal dunia. $^{31}$

Naskah Mushaf al-Qur`an ini tidak memiliki judul secara spesifik sebagaimana naskah lain yang ditemukan judul pada sampul depannya. Sampul depannya terbuat dari kulit dengan sisi sisi yang lembut seperti kapas. Disimpan oleh salah satu ahli waris pemilik naskah di rak lemari yang berada di dalam rumah. ${ }^{32}$ Mushaf ini merupakan jilid pertama, dari beberapa jilid yang memuat teks al-Qur`an secara lengkap. Jilid pertama ini dimulai dari surat al-Fātiḥaḥ hingga akhir Surat al-Baqarah ayat 178. Tidak terdapat keterangan yang menjelaskan tempat dan masa penyalinan mushaf. Mushaf ini juga tidak memiliki kolofon. Aspek kesejarahan mushaf di dapat melalui tuturan lisan pemilik naskah.

\footnotetext{
${ }^{30}$ Ibid., hlm. 304.

${ }^{31}$ Wawancara dengan Abdullah Ahmad Syadzili, 12 Desember 2018.

${ }^{32}$ Tempat penyimpanan mushaf kuno di Bangkalan dapat dikelompokkan menjadi tiga, yaitu museum, rumah tokoh masyarakat, dan langger. Dalam hal ini, naskah mushaf milik H. Habibullah tersimpan di dalam rumah.
} 

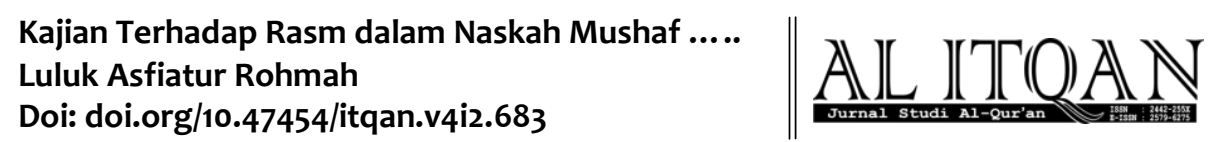

Secara keseluruhan kondisi naskah masih cukup baik, hanya saja pada bagian awalawal mushaf terlihat kecoklatan dengan bagian tepi sobek termakan usia. Kulit sampul depan bersambung (menjadi satu) dengan surat al-Fātiḥaḥ kemudian sampul belakang juga bersambung dengan ayat-ayat terakhir pada mushaf. Bagian tengah sampai akhir terdapat beberapa kertas yang kondisinya sudah berlubang pada sisi atas. Tulisannya masih terlihat jelas. Hanya beberapa halaman pada awal dan akhir yang warna tintanya terlihat memudar. (Gambar 1: Kondisi Naskah)

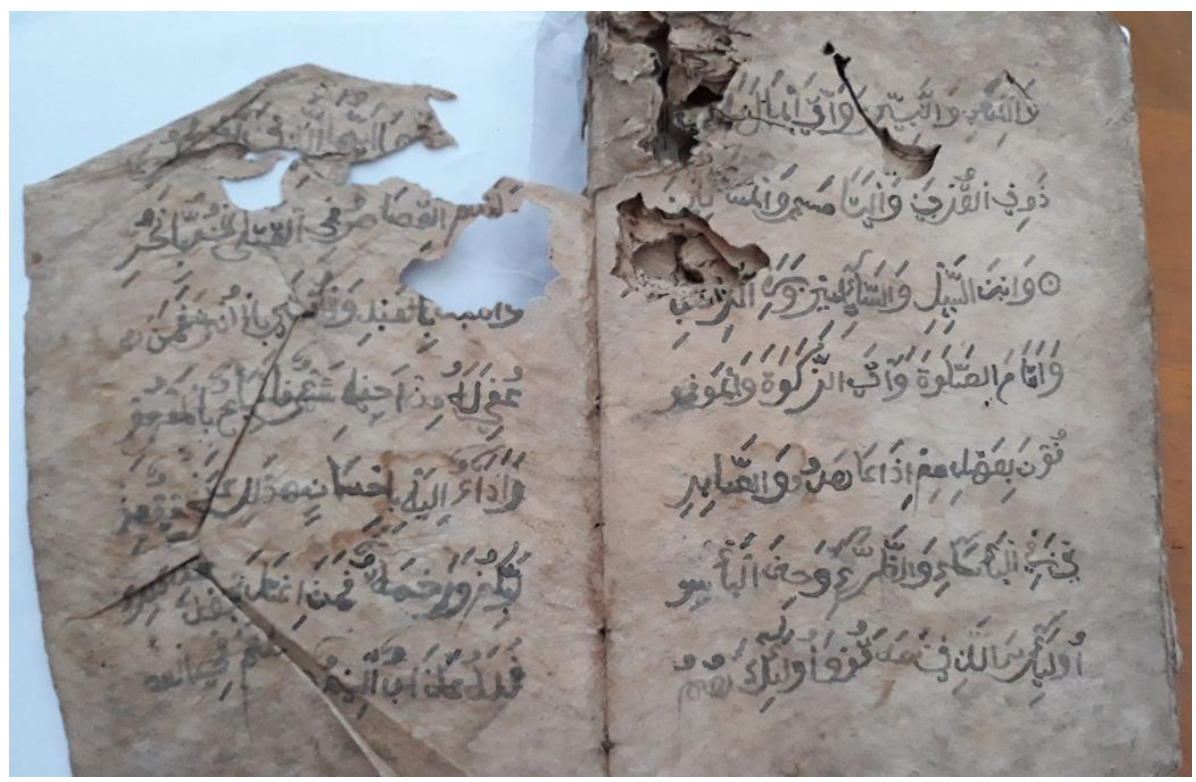

Gambar 1: Kondisi naskah.

Mushaf milik H. Habibulllah ini setiap halaman terdiri dari 7 baris, kecuali pada surat al-Fātiḥah terdiri dari 5 baris dengan garis-garis pembatas di pinggir teks sebagai bingkainya. Ukurannya tergolong standar, yaitu 17 x $13 \mathrm{~cm}$. Bidang teks berukuran 1,7 x 1/0,5 cm dengan ketebalan 1,5 cm. Jumlah halaman keseluruhan 103 halaman dengan dua halaman kosong tepat ditengah mushaf yaitu pada halaman 61 dan 62. Juga tidak terdapat penomoran halaman ataupun kata alihan (catch word) pada setiap halamannya, sehingga rentan tertukar halaman jika terlepas.Kertas yang digunakan adalah kertas dluwang ${ }^{33}$. Kemudian sistem penjilidannya

\footnotetext{
33 Dluwang atau daluang. Masyarakat Bangkalan mengenalnya Dalubhang atau kertas kapas. Daluwang merupakan kertas hasil produksi yang berbahan dasar kulit kayu pohon Broussonetia papyrifera Vent. Pohon ini dinamakan pohon sae dalam Bahasa Sunda. Bahan ini disebut dluwang atau dlacang dalam Bahasa Jawa, disebut daluwang dalam Bahasa Sunda atau ulantaga dalam Bahasa Bali. Kata daluwang sendiri sudah disebut sejak abad ke-9 dalam Kakawin Ramayana dan pada Kakawin Sumanasantaka (abad ke-12) dan merujuk pada jenis pakaian dari kulit kayu yang digunakan kaum pertapa. Naskah dluwang tertua saat ini diketahui adalah naskah yang disebut 'Kitab Undang-undang Tanjung Tanah' yang berasal dari sekitar abad ke-14. Naskah-naskah yang berbahan daluwang terutama berasal dari Jawa, Sunda, dan Madura, selain terdapat contoh kecil dari Sulawesi
} 
menggunakan benang yang disebut benang bol dengan mengaitkan satu halaman dengan halaman lain.

Tinta yang digunakan adalah tinta hitam dan merah. Teks al-Qur`anditulis dengan menggunakan khāt naskhī dengan menggunakan tinta berwarna hitam, dan tidak ditulis dengan kalam tebal tipis. Tinta berwarna merah digunakan untuk tanda akhir ayat yang berupa lingkaran merah dengan titik hitam kecil di dalamnya, tetapi ada pula yang diberi tanda lingkaran ayat dengan tinta warna hitam sekaligus merah dengan memberi titik hitam di dalamnya.Tidak semua akhir ayatdiberi tanda demikian (lingkaran ayat).Tanda ini kadang ada, kadang juga tidak ada.Hal tersebut terjadi bisa disebabkan karena terlewat.Karena kemungkinan, tanda lingkaran merah tersebut dibuat setelah selesai penulisan per halaman mushaf.Maka, dapat terlihat bahwa dalam mushaf ini hitam menjadi warna dominan dalam menulis ayat, selain warna merah yang berupa lingkaran pada akhir ayat.

Bagian pinggir ayat dibatasi dengan bingkai berupa garis segi empat dengan tinta warna hitam.Sehingga tidak terdapat iluminasi dalam mushaf ini, baik di awal, tengah maupun akhir.Hanya saja pinggiran-pinggiran ayat berupa garis-garis agar terlihat simetris dan ayat-ayat yang ditulis terlihat rapi dan tidak keluar dari garis.

Mushaf al-Qur`an milik H. Habibullah ini tidak menggunakan tanda baca seperti maqra', rubu', akan tetapi dalam mushaf ini menggunakan tanda perpindahan juz. Penandaan awal juz terdapat coretan seperti bunga-bunga di pojok awal juz dan berada di dalam garis pinggir teks ayat.Tanda baca tersebut tidak selengkap dan sedetail mushaf pada masa sekarang. Tanda wakafnyapun hanya menggunakan tanda $t \bar{a}^{\prime}$ (tanpa tanda $m \bar{\imath} m, q \bar{a} f$,dan jīm). Tanda tajwidnya tidak menggunakan simbol huruf seperti nūn, iẓhār, gīn untuk idgām bigunnah, lam-gìn untuk idgāmbilā ghunnah, khā' untuk ikhfā' dan mìm untuk iqlab.

Sebagaimana naskah tulisan tangan pada umumnya, dalam naskah ini juga terdapat kesalahan penulisan yang lumrah terjadi.Akan tetapi, disertakan juga beberapa koreksi kesalahan ayat yang ditulis dipinggir halaman.Perbaikan kesalahan ditulis dengan memberi coretan langsung pada ayat atau ditulis berdekatan dengan kalimat yang kurang.Perbaikan berupa kekurangan ayat dilakukan pada sambungan ayat yang kurang dan ditulis dipinggir halaman, atau memberi tanda seperti huruf nün kecil diletakkan disamping ayat yang kurang, kemudian lanjutan ayat ditulis dipinggir halaman.Namun, ada juga kesalahan penulisan ayat

Selatan dan Sumatera. Lihat https://www.pegipegi.com/travel/sejarah-perkembangan-kertas-di-indonesia/ (diakses pada tanggal 26 Maret 2018). 
Kajian Terhadap Rasm dalam Naskah Mushaf ..... Luluk Asfiatur Rohmah

Doi: doi.org/10.47454/itqan.v4i2.683

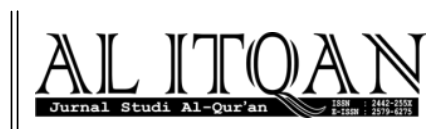

yang tidak terdapat koreksi di dalamnya, sehingga dibiarkan begitu saja.Mushaf ini belum menggunakan nomor ayat, hanya berupa titik kecil dan lingkaran hitam sekaligus merah.Kuat kemungkinan lingkaran merah dibuat kemudian dengan letaknya yang sedikit diatas ayat.

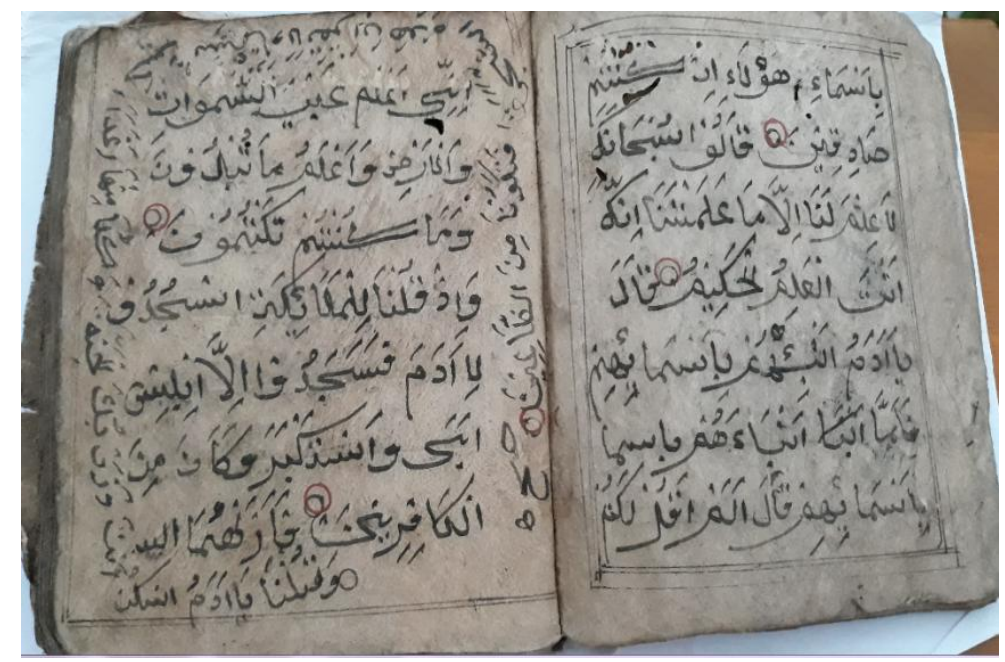

Gambar 2: Koreksi kekurangan ayat ditulis dipinggir halaman

\section{E. Penyalin Mushaf al-Qur`an dan Latar Belakang Penulisannya}

Naskah Mushaf al-Qur`andari Desa Konang ini tidak memiliki kolofon. Hal ini sedikit menyulitkan dalam melacak tahun penyalinan naskah dan siapa yang menyalinnya.Berdasarkan beberapa penuturan para pemiliknya, mushaf ini ditulis oleh kakek mereka (generasi di atas mereka) yang bernama Habibullah.

Habibullah adalah kakek mereka yang dulunya gemar menulis termasuk menulis alQur'an.Tujuan awal Habibullah menulis al-Qur`an untuk kepentingan ekonomi, karena pada masa itu membeli kertas masih sangat mahal. Kemudian ia mempunyai inisiatif menulis mushaf sebagai sarana baginya dalam menunaikan ibadah ke tanah suci Makkah. Setelah itu, mushaf ini dipakai sebagai sarana pengajaran dalam langgar yang berjarak sekitar 3 meter dari kediamannya. ${ }^{34}$

Habibullah adalah putra dari pasangan Muhammad Nur beserta ibu Ramlah yang berasal dari Desa Brambang, kecamatan Konang, Bangkalan Madura. Diperkirakan beliau lahir pada tahun 1848 M. Habibullah dibesarkan dalam lingkungan keluarga yang kental akan ajaran agama Islam. Disamping itu, ayahnya juga merupakan tokoh agama yang berpengaruh

\footnotetext{
${ }^{34}$ Wawancara dengan Abdullah Ahmad Syadzili,24 Januari 2018.
} 
dieranya.Ia merupakan anak sulung dari lima bersaudara yaitu Habibullah, Maimunah, Romlah, Rohmah serta Daimah. ${ }^{35}$

Sejak kecil Habibullah mendapatkan pendidikan dan bimbingan secara langsung dari ayahnya terutama pendidikan di bidang al-Qur`andan literatur agama lain, seperti pelajaran dasar-dasar tauhid, dan fikih. Ia juga aktif mengikuti pengajian yang dilakukan di langger ${ }^{36}$ bujuk $^{37}$ yang diasuh oleh ayahnya sendiri dan dilakukan setiap hari sehabis sholat maghrib dan isya'. Menginjak usia remaja, Habibullah aktif mengikuti kajian-kajian dari langgar ke langgar ${ }^{38}$, diantaranya langgar atau musala yang terletak di dusun Glugur yang diasuh oleh Bujuk Glugur (disebut Glugur karena beliau adalah seorang 'ālim dari daerah Glugur). Setelah melihat ketekunan dan kegigihan Habibullah dalam belajar, akhirnya sang guru tersebut tertarik untuk menjodohkannya dengan salah seorang putrinya yang bernama Siti Muniroh. ${ }^{39}$ Habibullah juga berkesempatan menimba ilmu kepada Mbah Kholil atau terkenal dengan sebutan Syaikhona Kholil, ulama berpengaruh di tanah Jawa. ${ }^{40}$

Setelah menikah dengan Siti Muniroh, kesibukan Habibullah sehari-hari seperti masyarakat pada umumnya.Pagi hingga siang hari, ia pergi ke sawah untuk bertani. Setelah sholat maghrib, barulah ia mengajarkan al-Qur`an kepada keluarga hingga para tetangga. Kajian al-Qur`an ini diikuti oleh anak-anak usia belasan tahun. Sedangkan al-Qur`an yang dipakai kala itu adalah al-Qur`an yang ia tulis sendiri. Habibullah wafat pada tahun 1963 dengan usia kurang lebih 120 tahun $^{41}$. Adapun karya-karya tulisan tangan Habibullah yang masih tersimpan hingga kini berupa karyanya di bidang Tauhid dan Nahwu.Karya tersebut disimpan di langger bujuk. ${ }^{42}$

Setelah Habibullah wafat naskah al-Qur`anyang berada di langger bujuk tersebut dipindahkan ke Desa Konang oleh salah seorang anaknya yaitu Ahmad Syadzili. Ahmad

\footnotetext{
${ }^{35}$ Wawancara dengan Abdul Fatah, 10 Maret 2018.

${ }^{36}$ Musalla.

${ }^{37}$ Bujuk dalam bahasa Madura berarti seseorang dari silsilah keluarga atau para leluhur yang dianggap 'alim serta dekat dengan Allah.

${ }^{38}$ Pada saat itu masih jarang ditemukan remaja yang menimba ilmu di pesantren. Ilmu yang mereka dapatkan dari pengajian yang diselenggarakan dari langgar ke langgar yang diajarkan oleh para ulama atau bujuk. Biasanya dilakukan sehabis solat maghrib dan isya'. Wawancara dengan Abdullah Ahmad Syadzili, 28 Maret 2018.

${ }^{39}$ Wawancara dengan Abdullah Ahmad Syadzili, 28 Maret 2018.

${ }^{40}$ Hal ini terbukti karena kakak dari istrinya yang bernama Yasin dijodohkan dengan putri Syaikhona Kholil. Maka, Bujuk Glugurdengan Syaikhona Kholil masih termasuk besan (dua keluarga yang telah menikahkan anak lelaki dan perempuannya).

${ }^{41}$ Wawancara dengan Abdul Fatah, 10 Maret 2018.

${ }^{42}$ Wawancara dengan Abdul Fatah, 10 Maret 2018.
} 
Kajian Terhadap Rasm dalam Naskah Mushaf ..... Luluk Asfiatur Rohmah

Doi: doi.org/10.47454/itqan.v4i2.683

Syadzili ini membawa naskah jilid pertama dan diletakkan di dalam rumahnya. Sedangkan naskah-naskah lain dibawa oleh ahli waris yang lain untuk menjaga serta mendapatkan barakah dengan menyimpannya. ${ }^{43}$

\section{F. Rasm pada Naskah Mushaf al-Qur`an Milik H. Habibullah Dari Desa Konang Bangkalan Madura}

Sub Bab ini akan mengupas klasifikasi bentuk penggunaan rasm pada Naskah Mushaf al-Qur`an H. Habibullah dengan mengaplikasikan Kaidah rasm Uthmānī Ghānim Qaddūr alḤamd dalam kitab al-Muyassar fì Ilm al-Rasm al-Muṣhaf wa Ḍabțihi

\section{Membuang Huruf}

a. Alif

Sebagaimana dalam naskah al-Qur`an ini yang dipaparkan dalam tabel berikut:

\begin{tabular}{|c|c|c|c|c|c|}
\hline \multirow{2}{*}{ No } & \multirow{2}{*}{$\begin{array}{l}\text { Surat/ } \\
\text { Ayat }\end{array}$} & \multirow{2}{*}{$\begin{array}{c}\text { Rasm Naskah } \\
\text { Mushaf }\end{array}$} & \multicolumn{2}{|c|}{ Rasm } & \multirow{2}{*}{ Keterangan Kaidah } \\
\hline & & & Uthmānī & $\operatorname{Imlā} i$ & \\
\hline 1. & $1 / 1$ & الْعَالَمِينَ & الْعُلَمِيَنَ & الْعَالَمِينَ & Tidak ada pembuangan huruf alif \\
\hline 2. & $2 / 130$ & الصَّالِِِينَ & الصُّلِحِينَ & الصَّالِِينَ & Tidak ada pembuangan huruf alif \\
\hline 3. & $2 / / 159$ & الأَعِنُْوْْنَ & اللَعِنْوُنَنَ & الأَعَعْنُوْنَ & Tidak ada pembuangan huruf alif \\
\hline 4. & $2 / 45$ & الخْنَاشِعِيْنِ & المُنْشِعِيْنِنِ & الخْنَاشِعِيْنِ & Tidak ada pembuangan huruf alif \\
\hline 5. & $\begin{array}{l}2 / 46 \\
2 / 156\end{array}$ & 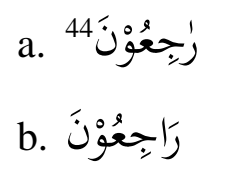 & رُجِعُوْنَ & رَاجِعُوْنَ & $\begin{array}{l}\text { Satu tempat dengan membuang } \\
\text { membuang alif dan satu tempat } \\
\text { yang lain dengan membuang alif }\end{array}$ \\
\hline 6. & $1 / 7$ & الضَّاَّلِّنْنَ & الضَّاَّلِيْنَنَ & الضَّاَّلَّنِنَ & Tidak ada pembuangan huruf alif \\
\hline 7. & $2 / 87$ & البَيَنَاتِ 45 & البَيِنْتِ & البَيِنَاتِ & Tidak ada pembuangan huruf alif \\
\hline
\end{tabular}

\footnotetext{
${ }^{43}$ Wawancara dengan Abdullah Ahmad Syadzili, 28 Maret 2018.

${ }^{44}$ Dua kalimat yang sama namun ditulis dengan rasm yang berbeda pada ayat lain.

45 Penulisan $t \bar{a}$ ' pada kalimat ini disebagian tempat menggunakan $t \bar{a}$ ' marbuțah (艹) dan tā' mabsutah (ت) diselainnya yakni ditemukan pada ayat 87 menggunakan $t \bar{a}$ ' mabsuțh serta pada ayat 92 dan 159 menggunakan tā' marbuțah.
} 


\begin{tabular}{|c|c|c|c|c|c|}
\hline \multirow{2}{*}{ No } & \multirow{2}{*}{$\begin{array}{c}\text { Surat/ } \\
\text { Ayat }\end{array}$} & \multirow{2}{*}{$\begin{array}{c}\text { Rasm Naskah } \\
\text { Mushaf }\end{array}$} & \multicolumn{2}{|c|}{ Rasm } & \multirow{2}{*}{ Keterangan Kaidah } \\
\hline & & & Uthmānn̄ & Imlā'i & \\
\hline 8. & $2 / 148$ & الخَيْرَاةٍ & الخَيْراتِ & الخيَرَاتِ & Tidak ada pembuangan huruf alif \\
\hline 9. & $2 / 151$ & أَيَاتِنَنَا & أيُينًَا & أبَاتِتَنَا & Tidak ada pembuangan huruf alif \\
\hline 10 & $\begin{array}{c}2 / 155 \\
2 / 22 \\
126\end{array}$ & 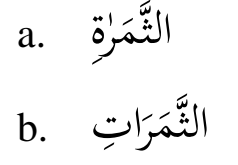 & الثَََّرَتِِِ & الثَّمَرَاتِ & $\begin{array}{l}\text { Satu tempat dengan membuang } \\
\text { membuang alif dan satu tempat } \\
\text { yang lain dengan membuang alif }\end{array}$ \\
\hline 11. & 2/167 & حَسَرَةٍ & حَسَرُبٍٍ & حَسَرَاتٍ & Tidak ada pembuangan huruf alif \\
\hline 12. & $2 / 102$ & يُعَلِلِمَانِ & & يُعَلِّمَان & Tidak ada pembuangan huruf alif \\
\hline 13. & $2 / 125$ & إِسمِْْعْيْلَ & راِسمْعِعْيلَ & إِسْمَاعِيْلَ & Hadhf Alif \\
\hline 14. & 2/133 & إسنْحَقَ & إسنْحَقَ & إسنحَاقَ & Hadhf Alif \\
\hline 15. & $\begin{array}{l}2 / 132, \\
2 / 130\end{array}$ & 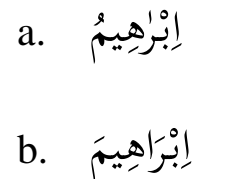 & اُبْرُهِيمَ & الِبْرَاهِيَمَ & $\begin{array}{l}\text { Satu tempat dengan membuang } \\
\text { membuang alif dan satu tempat } \\
\text { yang lain dengan membuang alif }\end{array}$ \\
\hline 16. & $2 / 63$ & أتَيْنَاكُكْمْ & عَاتَيَنْكُْْْ & أَتَيَنَاكُكُمْ & Tidak ada pembuangan huruf alif \\
\hline 17. & $2 / 2$ & ذَلِكِكَ & ذَلِكِكَ & ذَالِكَ & Hadhf Alif \\
\hline 18. & 2/36 & مَتَّاعُ & مَتْعُ & مَتَّاعُ & Tidak ada pembuangan huruf alif \\
\hline 19. & $2 / 82$ & آَصْحَابُ & اَصْحُبِ & 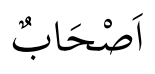 & Tidak ada pembuangan huruf alif \\
\hline 20. & $1 / 3$ & مَالِكِكِ & مُلِكِ & مَالِكِك & Tidak ada pembuangan huruf alif \\
\hline
\end{tabular}

\footnotetext{
${ }^{46}$ Jika terdapat perbedaan penulisan rasm Uthmānī antara shaikhān̄̄ rasm Uthmānī menurut Ghānīm Qaddurī, maka kedua madzhab ditulis. Dengan ketentuan “a." pendapat al-Dānī dan "b." pendapat Abū Dāwud.
} 
Kajian Terhadap Rasm dalam Naskah Mushaf ..... Luluk Asfiatur Rohmah

Doi: doi.org/10.47454/itqan.v4i2.683

\begin{tabular}{|c|c|c|c|c|c|}
\hline \multirow{2}{*}{ No } & \multirow{2}{*}{$\begin{array}{l}\text { Surat/ } \\
\text { Ayat }\end{array}$} & \multirow{2}{*}{$\begin{array}{c}\text { Rasm Naskah } \\
\text { Mushaf }\end{array}$} & \multicolumn{2}{|c|}{ Rasm } & \multirow{2}{*}{ Keterangan Kaidah } \\
\hline & & & Uthmānī & $\operatorname{Imlā'} i$ & \\
\hline 21. & $2 / 9$ & يُنَادِعْوُنَ & يُخْدِعُوْْنَ & يُخَادِدعُونَ & Tidak ada pembuangan huruf alif \\
\hline 22. & $2 / 21$ & يآآيُهَها & يَايَّْهَا & يآآيَهُها & Tidak ada pembuangan huruf alif \\
\hline
\end{tabular}

Pembuangan alif dalam naskah al-Qur`an ini sebagian ditulis menggunakan rasm imlà' $\bar{l}$ dansebagian lain ditulis dengan rasmUthmānì. Sedangkan pembuangan alif yang terdapat pada kalimat-kalimat jama' mudhakar sālim mayoritas ditulis menggunakan rasmimlā' $’ \bar{l}$ (dengan menetapkan alif).

Hal tersebut dapat disimpulkan bahwa dalam penulisan naskah Mushaf al-Qur'an, H. Habibullah ini terjadi inkonsistensi penulisan. Realita-realita di atas menujukkan bahwa standar penulisan jama' mudhakar sālim dan jama' mu'annath sālim pada naskah tersebut beberapa kalimat menggunakan rasmUthmānī, kemudian mayoritas menggunakan rasm imlā' 't. Meskipun masih terdapat lafal pada satu ayat kemudian ditulis dengan rasm berbeda pada ayat lain atau pada jama' mu'annath sālim terdapat lafal yang sama dengan penggunaan huruf berbeda.

Dari hasil penyisiran, d̦amìr rafa' yang sambung dengan damīr lainnya dalam naskah

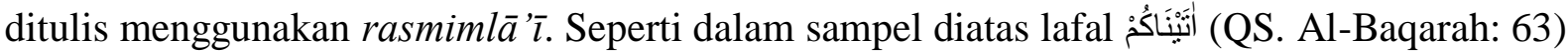
dan juga pada ayat 93 dengan lafal yang sama, yakni dengan menetapkan alif. Adapun untuk penulisan nama-nama 'ajam pada lafal إِنْمِيْيْل (QS. Al-Baqarah: 125) semuanya ditulis menggunakan rasm Uthmānī dengan membuang alif, yakni pada ayat 125, 127, 133, 140 dan ayat 136. Dan lafal إنْحَقَ (QS. Al-Baqarah: 133) yang terdapat pada ayat 133, 136 dan 140. Berbeda ketika penulisan إِْرَا هِيَْ (QS. Al-Baqarah: 130) di mana lafal tersebut ditulis dengan rasmimlā' '̄, yakni pada ayat $125,126,127,130,133,135$, dan 140, dan yang ditulis dengan rasm Uthmānī hanya pada ayat 132 .

Pembuangan alif yang tidak berdasarkan kesesuaian kaedah atau tanpa kaedah dengan ditetapkannya dalam semua lafal ذلِّف dalam naskah H. Habibullah. Namun pada beberapa kalimat lain, lebih banyak menggunakan rasm imlā 'ڤ

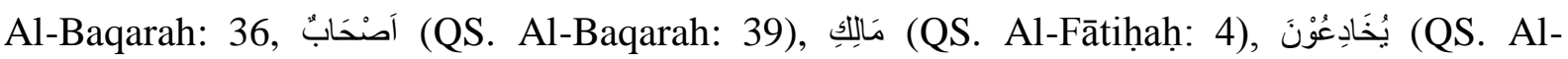




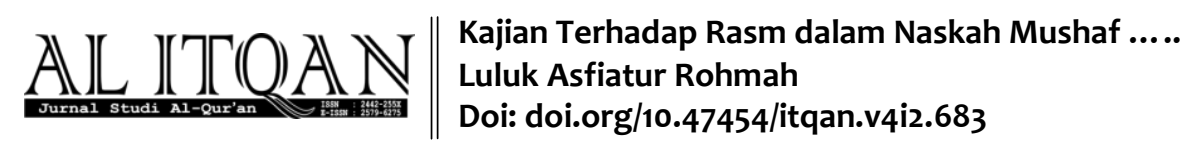

Baqarah: 9), يآئهَا (QS. Al-Baqarah: 21) yaitu pembuangan alif tidak berlaku dalam naskah Mushaf al-Qur`an tersebut.

Maka, pembuangan alif pada mushaf H.Habibullah dari desa Konang ini, mayoritas menggunakan kaidah penulisan rasm imlā' $\bar{l}$. Serta beberapa lainnya menggunakan kaidah rasm Uthmān̄i. Dan ada beberapa kalimat yang ditulis dengan rasm imlā' $\bar{\imath}$ pada suatu ayat namun terdapat kalimat yang sama pada ayat lain menggunakan rasm Uthmānī. Hal ini menunjukkan bahwa mushaf $H$. Habibullah masih belum konsisten dalam standar penulisannya.

b. Y $\overline{\mathbf{a}}$

Pembuangan huruf $y \bar{a}^{\prime}$ terdapat pada beberapa kalimat di al-Qur'an, sebagaimana dalam naskah al-Qur`an H. Habibullah pada tabel berikut:

\begin{tabular}{|c|c|c|c|c|c|}
\hline \multirow{2}{*}{ No } & \multirow{2}{*}{$\begin{array}{c}\text { Surat/ } \\
\text { Ayat }\end{array}$} & \multirow{2}{*}{$\begin{array}{c}\text { Rasm } \\
\text { Naskah } \\
\text { Mushaf }\end{array}$} & \multicolumn{2}{|c|}{ Rasm } & \multirow[b]{2}{*}{ Keterangan Kaidah } \\
\hline & & & Uthmān̄̄ & $\operatorname{Imlā'̄~}$ & \\
\hline 1. & $2 / 177$ & النَّبِّنَنَ & النَّبِّزنَ & النَّبيّنَ & Hadhfya' \\
\hline 2. & $2 / 26$ & يَسْتَحْيْيْ & يَسْتَحْي & يَسْتَحْيْيْ & Tidak ada pembuangan huruf $y a$, \\
\hline 3. & $2 / 28$ & يُجِْيْنكُمْ & يُجِْيْنكُمْ & يُجِِِيْكُمْ & Tidak ada pembuangan huruf $y a$ ' \\
\hline 4. & $2 / 40$ & فَارْهَبُوْنِ & فَارْهَبُوْنِ & فَارْهَبْوْْني & Hadhfya' \\
\hline 5. & $2 / 41$ & فَاتَّقُوْنِ & فَاتَقُُوْنِ & فَاتَّقُوْْني & Hadhfya' \\
\hline 6. & $2 / 152$ & وَلاَ تَكْفْرُوِْْن & وَلاَ تَكَفْرُوِْْنِ & وَلاَ تَكَفْرُوْرْْي & Hadhfya' \\
\hline 7. & $2 / 54$ & يَاقَوْْرُ إنَّكُْمُ & يُقَوْْر رانِكَكْمُ & يَاقَوْْرُ الِنَّكُمْ & Tidak ada pembuangan huruf $y a$, \\
\hline 8. & $2 / 61$ & يَا مُوْسَى & 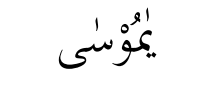 & يَا مُوْسَى & Tidak ada pembuangan huruf $y a$, \\
\hline 9. & $2 / 33$ & 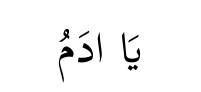 & 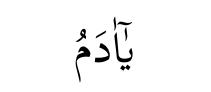 & 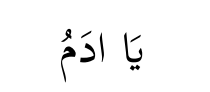 & Tidak ada pembuangan huruf $y a$ ' \\
\hline 10. & $2 / 130$ & إبْرَاهِيمَ & 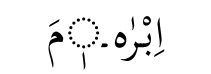 & إِبْرَاهِيَمَ & Tidak ada pembuangan huruf $y a$, \\
\hline
\end{tabular}


Kajian Terhadap Rasm dalam Naskah Mushaf ..... Luluk Asfiatur Rohmah

Doi: doi.org/10.47454/itqan.v4i2.683

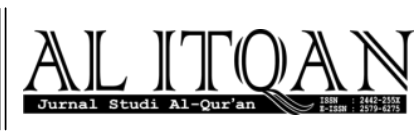

Maka, standar pembuangan $y \bar{a}$ ' dalam naskah al-Qur`an H.Habibullah, beberapa menggunakan rasm Uthmān̄̄ menurut Ghānīm Qaddūrī. Dan beberapa lainnya ditulis menggunakan rasm imlā' $\bar{\imath}$. Akan tetapi tidak semua kaedah pembuangan $y \bar{a}$ ' ditemukan dalam naskah ini mengingat naskah Mushaf al-Qur`an hanya terbatas sampai ayat 178 surat al-Baqarah.

\section{c. Lām}

Standar pembuangan lam pada naskah al-Qur`an H. Habibullah terdapat pada lafallafal dalam tabel berikut:

\begin{tabular}{|c|c|c|c|c|c|}
\hline \multirow[b]{2}{*}{ No } & \multirow{2}{*}{$\begin{array}{l}\text { Surat/ } \\
\text { Ayat }\end{array}$} & \multirow{2}{*}{$\begin{array}{c}\text { Rasm } \\
\text { Naskah } \\
\text { Mushaf }\end{array}$} & \multicolumn{2}{|c|}{ Keterangan } & \multirow[b]{2}{*}{ Keterangan Kaidah } \\
\hline & & & $\begin{array}{c}\text { Rasm } \\
\text { Uthmān̄̄ }\end{array}$ & $\begin{array}{l}\text { Rasm } \\
\text { Imlā' } \overline{1}\end{array}$ & \\
\hline 1. & $2 / 46$ & اللَّذِيْنَ & لَذِيْنَ & اللَّذِيْنَ & Hadhf Lam pada isim maușūl \\
\hline 2. & $2 / 22$ & اللَّنِيْ & اللَِّْيْ & اللَّذِيْ & Hadhf Lam pada isim maușūl \\
\hline 3. & $2 / 24$ & التَّيْ & التِّيْ & اللَتِِْ & Hadhf Lam pada isim mauṣūl \\
\hline 4. & $2 / 159$ & اللاعِنْوُنَ & اللَعْنُوْنَنَ & الأَعِنْوُونَ & Tidak ada pembuangan huruf Lam \\
\hline
\end{tabular}

Kaidah Hadhf Lam terdapat pengecualian untuk penulisan al-Ta'rïf yang masuk pada suatu kalimat yang diawali huruf lām seperti lafal النالِنْوْنَ (QS. Al-Baqarah: 159) dalam naskah ditulis dengan menetapkan dua lām namun tetap sesuai dengan kaedah rasmUthmānī. Hal tersebut menunjukkan bahwa standar pembuangan lām dalam naskah ini menggunakan rasm Uthmānī secara konsisten.

\section{Penambahan Huruf}

Penambahan huruf pada rasm Uthmān̄̄ di dalam al-Qur`an terdapat pada huruf alif, $y \bar{a}$ ' dan $w \bar{a} w u$.

\section{a. Alif}

Penambahan alif dalam al-Qur`an terdapat pada beberapa kalimat dalam al-Qur'an. Akan tetapi dalam naskah Mushaf al-Qur`an ini hanya terdapat setelah wāwu jama' yang berada di akhir kalimat $f i$ 'il. Seperti yang terdapat dalam tabel berikut: 


\begin{tabular}{|c|c|c|c|c|c|}
\hline \multirow[b]{2}{*}{ No } & \multirow[b]{2}{*}{$\begin{array}{l}\text { Surat/ } \\
\text { Ayat }\end{array}$} & \multirow{2}{*}{$\begin{array}{c}\text { Rasm } \\
\text { Naskah } \\
\text { Mushaf }\end{array}$} & \multicolumn{2}{|c|}{ Keterangan } & \multirow[b]{2}{*}{ Keterangan Kaidah } \\
\hline & & & $\begin{array}{c}\text { Rasm } \\
\text { Uthmānī }\end{array}$ & $\begin{array}{l}\text { Rasm } \\
\text { Imlā'̄i }\end{array}$ & \\
\hline 1. & $2 / 9$ & أَمَنُوْا & أَمَنُوْا & أَمَنُوْا & Ziyadah Alif setelah wāwu jama' \\
\hline 2. & $2 / 11$ & لَا تُفْسِدُوْا & لَا تُفْسِدُوْا & لَا تُفْسِدُوْا & Ziyadah Alif setelah wāwu jama' \\
\hline 3. & $2 / 6$ & كَفَرُوْا & كَفَرُوْْا & كَفَرُوْا & Ziyadah Alif setelah wāwu jama' \\
\hline 4. & $2 / 14$ & لَقُو & لَقُوا & كَقُوا & Tidak ada penambahan huruf alif \\
\hline 5. & $2 / 61$ & وَبَآعُوْْا & وَبَاََُوُْو & وَبَآعُوْاُ & Ziyadah Alif setelah wāwu jama' \\
\hline
\end{tabular}

Lafal-lafal di atas terdapat penambahan alif yang terjadi setelah wāwu jama' yang berada di akhir kalimat fi'il. Kecuali pada lafal لَقُ (QS. Al-Baqarah:14) tertulis dengan tanpa alif. Artinya, penulisan lafal ini tidak mengikuti kaedah tertentu baik kaedah rasm Uthmān̄̄ maupun rasm imlà' $\bar{l}$.Di samping itu, dalam ayat ini, ada dua kalimat fi'il (yang terdapat penambahan alif di akhir kalimatnya) ditulis menggunakan rasm Uthmānī.

Mayoritas penambahan alif pada kalimat fi'il dalam naskah H.Habibullah sesuai dengan kaedah rasm Uthmān̄ì. Sebagian lainnya menggunakan rasm imlā'̄o. Meski demikian, tetap tidak dapat dikatakan bahwa kaedah yang digunakan sudah konsisten, mengingat masih terdapat lafal-lafal dalam naskah yang tidak mengikuti kaedah tertentu.

\section{b. Wāwu}

Ziyadah wāwu pada mushaf al-Qur`an H. Habibullah hanya terdapat pada kalimat berikut:

\begin{tabular}{|c|c|c|c|c|c|}
\hline \multirow{2}{*}{ No } & \multirow{2}{*}{$\begin{array}{l}\text { Surat } \\
\text { /Ayat }\end{array}$} & \multirow{2}{*}{$\begin{array}{l}\text { Rasm Naskah } \\
\text { Mushaf }\end{array}$} & \multicolumn{2}{|c|}{ Rasm } & \multirow{2}{*}{ Keterangan Kaidah } \\
\hline & & & Uthmānn̄ & Imlā'‘ & \\
\hline 1. & $2 / 5$ & أُولَكِكَ & أو لُكَكَكَ & أُولَكِكَ & $\begin{array}{c}\text { Ziyadah pada hamzah yang } \\
\text { berharakat dummah }\end{array}$ \\
\hline
\end{tabular}

Penambahan huruf $w \bar{a} w u$ pada naskah H.Habibullah hanya ditemukan pada lafal (QS. Al-Baqarah: 5). Penambahan ini terjadi pada seluruh lafal أولَّْكَ dalam naskah. Maka, dapat dikatakan penambahan huruf $w \bar{a} w u$ didalam naskah al-Qur`an ini sudah konsisten. 
Kajian Terhadap Rasm dalam Naskah Mushaf ..... Luluk Asfiatur Rohmah

Doi: doi.org/10.47454/itqan.v4i2.683

\section{Penulisan Hamzah}

\section{a. Hamzah di awal kalimat}

Hamzah di awal kalimat dalam naskah ini terdapat pada kalimat-kalimat berikut:

\begin{tabular}{|c|c|c|c|c|c|}
\hline \multirow{2}{*}{ No } & \multirow{2}{*}{$\begin{array}{l}\text { Surat } \\
\text { /Ayat }\end{array}$} & \multirow{2}{*}{$\begin{array}{c}\text { Rasm } \\
\text { Naskah } \\
\text { Mushaf }\end{array}$} & \multicolumn{2}{|c|}{ Rasm } & \multirow{2}{*}{ Keterangan Kaidah } \\
\hline & & & Uthmānī & Rasm Imlā'̄ & \\
\hline 1. & $1 / 5$ & إِيَّكَ & إِيَّكَ & إِيَّاكَك & $\begin{array}{c}\text { Hamzah ditulis dengan alif karena } \\
\text { berharakat }\end{array}$ \\
\hline 2. & $2 / 27$ & 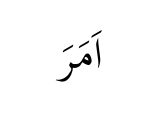 & أَََرَ & أَمَرَ & $\begin{array}{c}\text { Hamzah ditulis dengan alif karena } \\
\text { berharakat }\end{array}$ \\
\hline 3. & $2 / 4$ & أنزِْْ & أُنَِْْ & أُنْزَلَ & $\begin{array}{c}\text { Hamzah ditulis dengan alif karena } \\
\text { berharakat }\end{array}$ \\
\hline
\end{tabular}

Berdasarkan tabel di atas, penulisan hamzah sesuai penulisan Rasm Uthmānī dan Rasm Imlā'̄i. Namun bedanya, dalam naskah tidak menyertakan kode hamzah pada alif.

\section{b. Hamzah di tengah kalimat}

Hamzah di tengah kalimat adakalanya hamzahnya dibaca sukun dan adakalanya berharakat. Seperti kalimat-kalimat berikut:

\begin{tabular}{|c|c|c|c|c|c|}
\hline \multirow{2}{*}{ No } & \multirow{2}{*}{$\begin{array}{l}\text { Surat } \\
\text { /Ayat }\end{array}$} & \multirow{2}{*}{$\begin{array}{l}\text { Rasm Naskah } \\
\text { Mushaf }\end{array}$} & \multicolumn{2}{|c|}{ Rasm } & \multirow{2}{*}{ Keterangan Kaidah } \\
\hline & & & Uthmānī & Imlā' & \\
\hline 1. & $\begin{array}{c}2 / 12 \\
6\end{array}$ & وَبُْْسَ & وَبِيْسَ & وَبِيْسَ & $\begin{array}{l}\text { Hamzah ditulis dengan } y \bar{a} \text { ' karena } \\
\text { hamzah sukun jatuh setelah kasrah }\end{array}$ \\
\hline 2. & $2 / 54$ & & كُكْ & رِكِكُمْ & $\begin{array}{l}\text { Hamzah ditulis dengan } y \bar{a} \text { ' karena } \\
\text { hamzah sukun jatuh setelah kasrah }\end{array}$ \\
\hline 3. & $2 / 40$ & إسْرَاَعِيْلَ & اسِترَاَكِيْلَ & إسْرَاَعِيْلَ & $\begin{array}{l}\text { Hamzah ditulis sendiri tanpa huruf } \\
\text { karena hamzah berharakat kasrah } \\
\text { dan setelahnya ada } y a^{\prime}\end{array}$ \\
\hline
\end{tabular}

Tiga model penulisan hamzah di tengah kalimat tersebut telah sesuai dengan kaidah rasm Uthmānī, sehingga standar penulisan hamzah di sini telah konsisten dengan rasm Uthmānī.

\section{c. Hamzah di Akhir Kalimat}

Hamzah diakhir kalimat maka tidak ditulis dengan huruf tertentu apabila huruf sebelumnya di sukun.Ditemukan satu tempat dalam naskah al-Qur`an ini, yaitu: 


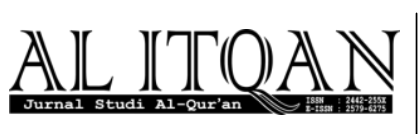

Kajian Terhadap Rasm dalam Naskah Mushaf .....

Luluk Asfiatur Rohmah

Doi: doi.org/10.47454/itqan.v4i2.683

\begin{tabular}{|c|c|c|c|c|c|}
\hline \multirow{2}{*}{ No } & \multirow{2}{*}{$\begin{array}{l}\text { Surat } \\
\text { /Ayat }\end{array}$} & \multirow{2}{*}{$\begin{array}{c}\text { Rasm Naskah } \\
\text { Mushaf }\end{array}$} & \multicolumn{2}{|c|}{ Rasm } & \multirow{2}{*}{ Keterangan Kaidah } \\
\hline & & & Uthmānī & $\operatorname{Imlā'} \bar{\imath}$ & \\
\hline 1. & $2 / 20$ & شَيٍٍْ & شَيٍٍْ & شَيٍٍْ & $\begin{array}{l}\text { Hamzah tidak ditulis dengan huruf } \\
\text { tertentu karena jatuh setelah huruf } \\
\text { yang disukun }\end{array}$ \\
\hline
\end{tabular}

Dalam naskah, penulis menemukan satu sampel contoh yang dapat mewakili bentuk penulisan hamzah di akhir kalimat. Sehingga dapat mewakili bentuk rasm hamzah pada naskah tersebut yakni pada lafal (QS. Al-Baqarah: 20). Hamzah di sini tidak ditulis dengan huruf tertentu karena huruf sebelumnya disukun, sesuai dengan kaidah RasmUthmānī dan RasmImlā'

\section{Penggantian Huruf}

Terdapat beberapa penggantian huruf di dalam al-Qur'an, yaitu:

\section{a. Alif Ditulis dengan $W \bar{a} w u$}

Dalam naskah al-Qur`an H. Habibullah penggantian huruf alif dengan wāwu terdapat di tiga tempat. Seperti pada tabel berikut:

\begin{tabular}{|c|c|c|c|c|c|}
\hline \multirow{2}{*}{ No } & \multirow{2}{*}{$\begin{array}{l}\text { Surat } \\
\text { /Ayat }\end{array}$} & \multirow{2}{*}{$\begin{array}{c}\text { Rasm Naskah } \\
\text { Mushaf }\end{array}$} & \multicolumn{2}{|c|}{ Rasm } & \multirow{2}{*}{ Keterangan Kaidah } \\
\hline & & & Uthmānī & $\operatorname{Imlā'}{ }^{\prime}$ & \\
\hline 1. & $2 / 45$ & الصَّلَوةِ & الصَّلَوةِ & الصَّاَلَةِ & Badal al-alif bi al-wawi \\
\hline 2. & $2 / 43$ & الزَّكَة & الزَّكوةً & الزَّكَةً & Badal al-alif bi al-wawi \\
\hline 3. & $2 / 85$ & الخَلْيَوِة & الحَيْوَةِ & الحَيَْاةِ & Badal al-alif bi al-wawi \\
\hline
\end{tabular}

Tabel kalimat al-Badl di atas menunjukkan naskah Mushaf al-Qur`an H.Habibullah patuh pada kaidah al-Badlrasm Uthmānī.Terutama lafal sama الصَّلوةٍ yang terdapat pada ayat 43 dan 45 serta lafal الْحَيَوِ pada ayat 85 dan 86 semua ditulis secara konsisten menggunakan rasm Uthmānī. Realita-realita ini menandakan bahwa kaedah badl alif dengan wāwu sudah diterapkan dalam seluruh mushaf.

\section{b. Alif Ditulis dengan $Y \bar{a}$}

Ada empat tempat penggantian alif ditulis dengan $y \bar{a}^{\prime}$ yang terdapat dalam naskah alQur`an ini. Seperti dalam tabel di bawah ini: 
Kajian Terhadap Rasm dalam Naskah Mushaf ..... Luluk Asfiatur Rohmah

Doi: doi.org/10.47454/itqan.v4i2.683

\begin{tabular}{|c|c|c|c|c|c|}
\hline \multirow[b]{2}{*}{ No } & \multirow{2}{*}{$\begin{array}{c}\text { Surat/ } \\
\text { Ayat }\end{array}$} & \multirow{2}{*}{$\begin{array}{c}\text { Rasm } \\
\text { Naskah } \\
\text { Mushaf }\end{array}$} & \multicolumn{2}{|c|}{ Keterangan } & \multirow[b]{2}{*}{ Keterangan Kaidah } \\
\hline & & & $\begin{array}{c}\text { Rasm } \\
\text { Uthmānī }\end{array}$ & $\begin{array}{l}\text { Rasm } \\
\text { Imlā' } \overline{1}\end{array}$ & \\
\hline 1. & $2 / 2$ & هُدًا & لهُدَى & هُدَى & Tidak ada $a l$ - $B a d l$ alif dengan $y a$, \\
\hline 2. & $2 / 51$ & مُوَْى & مُوْسَى & مُوْسَى & Badal al-alif bi al-ya'i \\
\hline 3. & $2 / 81$ & بَلَى & 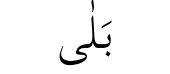 & 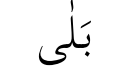 & Badal al-alif bi al-ya'i \\
\hline 4. & $2 / 5$ & عَلْى & عَلْى & تلمى ( تلى & Badal al-alif bi al-ya'i \\
\hline
\end{tabular}

Penetapan alif pada pada lafal (QS manapun baik rasm Uthmān̄ dan rasm imlā' $\bar{l}$. Hal ini dimungkinkan terdapat kesalahan penulisan atau penyalin mushaf belum mengerti kaedah penulisan tertentu. Maka, penulisan badl alif diganti $y \bar{a}$ ' dalam naskah H.Habibullah beberapa lafal sudah sesuai dengan kaedah rasm Uthmānī sekaligus imlā' $\bar{\imath}$.

\section{c. Hā Ta'nīth ditulis $T \bar{a}$}

Tidak terdapat penulisan $h \bar{a}$ ' ta'nith diganti $t \bar{a}$ ' di dalam naskah Mushaf al-Qur`an dari Madura ini. Karena memang penulisan $h \bar{a}$ ' ta'nith yang diganti $t \bar{a}$ ' hanya terbatas pada suratsurat tertentu. Tidak semua $h \bar{a}^{\prime}$ ta 'nith di dalam al-Qur`an ditulis dengan huruf $t \bar{a}$.

\section{Menyambung dan Memisah Tulisan}

Kalimat-kalimat dalam al-Qur`an terdapat beberapa ditulis secara terpisah dan tersambung dengan yang lainnya. Ada dua jenis faṣl dan waṣl dalam al-Qur`an yaitu:

\section{a. Menyambung dan Memisah Kalimat yang Menyebabkan Idghām}

Terdapat beberapa kalimat dalam naskah al-Qur`an H. Habibullah yang terjadi faṣl dan waṣl yang menyebabkan idghām. Namun tidak seperti yang telah disebutkan Ghānim Qaddūrī bahwa al-Mahdawī menyebutkan berada di delapan tempat. Di dalam naskah milik H. Habibullah hanya terdapat beberapa saja. Sebagaimana dalam tabel di bawah ini:

\begin{tabular}{|c|c|c|c|c|c|}
\hline \multirow{2}{*}{ No } & \multirow{2}{*}{$\begin{array}{l}\text { Surat/ } \\
\text { Ayat }\end{array}$} & \multirow{2}{*}{$\begin{array}{c}\text { Rasm Naskah } \\
\text { Mushaf }\end{array}$} & \multicolumn{2}{|c|}{ Rasm } & \multirow{2}{*}{ Keterangan Kaidah } \\
\hline & & & Uthmānì & $\operatorname{Imla}{ }^{\prime} \bar{\imath}$ & \\
\hline 1. & $2 / 3$ & مِ & & , & من + ما \\
\hline
\end{tabular}




\begin{tabular}{|c|c|c|c|c|c|}
\hline \multirow{2}{*}{ No } & \multirow{2}{*}{$\begin{array}{l}\text { Surat/ } \\
\text { Ayat }\end{array}$} & \multirow{2}{*}{$\begin{array}{c}\text { Rasm Naskah } \\
\text { Mushaf }\end{array}$} & \multicolumn{2}{|c|}{ Rasm } & \multirow{2}{*}{ Keterangan Kaidah } \\
\hline & & & Uthmānī & $\operatorname{Imlā'`}$ & \\
\hline 2. & $2 / 114$ & رَمَّنْ & رِمَّنْ & رِكَّنْ & مِن + مَن \\
\hline 3. & $2 / 74$ & عَمََّّا & عَمََّّا & عَمََّّا & عَنْ + ماً \\
\hline 4. & $2 / 24$ & فَانْ لَُّه & فَاِنْ لَّْْ & فَانْن لَُّْ & فَاِنْ + \\
\hline 5. & $2 / 26$ & آََّّا & آَهَّا & آَََّّا & آَ + ما \\
\hline
\end{tabular}

Dari lima di atas, naskah Mushaf al-Qur`an ini menerapkan kaidah al-fașlwawașl dalam rasm Uthmānī pada kalimat-kalimat yang menyebabkan idghām. Artinya, kalimatkalimat tersebut ketika dibaca maka otomatis dibaca idghām. Hal tersebut menandakan adanya ketetapan (konsisten) dalam kaedah faṣl dan waṣl dalam naskah al-Qur`an ini. Serta bisa dipastikan bahwa cara penulisannya telah diterapkan di seluruh naskah al-Qur`an ini.

\section{b. Menyambung dan Memisah Kalimat yang Tidak Menyebabkan Idghām}

Penyambungan dan pemisahan kalimat yang tidak menyebabkan idghām, seperti pada tabel berikut:

\begin{tabular}{|c|c|c|c|c|c|}
\hline \multirow{2}{*}{ No } & \multirow{2}{*}{$\begin{array}{l}\text { Surat/ } \\
\text { Ayat }\end{array}$} & \multirow{2}{*}{$\begin{array}{c}\text { Rasm } \\
\text { Naskah } \\
\text { Mushaf }\end{array}$} & \multicolumn{2}{|c|}{ Rasm } & \multirow{2}{*}{ Keterangan Kaidah } \\
\hline & & & Uthmān̄̄ & $\operatorname{Imlā'}$ & \\
\hline 1. & $2 / 113$ & فِيْمَا & فِيْمَا & فِيْ مَا & $\begin{array}{l}\text { Wașl kalimat yang tidak } \\
\text { menyebabkan idghām }\end{array}$ \\
\hline 2. & $2 / 93$ & بِيْسَمَا & بِيْسَمَا & بِيْسَسَمَا & $\begin{array}{l}\text { Wașl kalimat yang tidak } \\
\text { menyebabkan idghām }\end{array}$ \\
\hline 3. & $2 / 102$ & وَلَبَْْسَ مَا & وَلَبَْْسَ مَا & وَلَبَْْسَ مَا & $\begin{array}{l}\text { Wașl kalimat yang tidak } \\
\text { menyebabkan idghām }\end{array}$ \\
\hline 4. & $2 / 115$ & فَاَيْنَمَا & فَاَيْنَمَا & فَايَيْنَ مَا & $\begin{array}{l}\text { Wașl kalimat yang tidak } \\
\text { menyebabkan idghām }\end{array}$ \\
\hline 5. & $2 / 87$ & اَفَكَكُلَّمَا & اَفَكَكُلَّمَا & اَفَكَكَُّ مَا & $\begin{array}{l}\text { Wașl kalimat yang tidak } \\
\text { menyebabkan idghām }\end{array}$ \\
\hline 6. & $2 / 144$ & حَيْثُ مَا & حَيْثُ مَا & حَيْتُ مَا & $\begin{array}{l}\text { Wașl kalimat yang tidak } \\
\text { menyebabkan idghām }\end{array}$ \\
\hline
\end{tabular}


Kajian Terhadap Rasm dalam Naskah Mushaf ..... Luluk Asfiatur Rohmah

Doi: doi.org/10.47454/itqan.v4i2.683

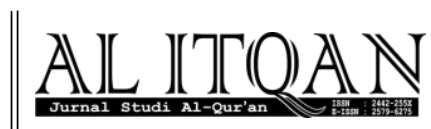

Penulisan naskah Mushaf al-Qur`an ini sangat petuh dan konsisten pada kaidah penulisan al-faṣlwawaṣlRasmUthmānī.

\section{G. Penulisan Harakat dan Tanda Baca}

\section{Harakat}

Penggunaan harakat pada naskah Mushaf al-Qur`an H.Habibullah seperti mushafmushaf pada umumnya. Sebagaimana tanda harakat yang dicetuskan oleh al-Khalīl bin Aḥmad al-Farāhidī. Harakat fatḥaḥ di dalam naskah ditandai dengan alif kecil melintang di atas huruf. Kasrah ditandai dengan bentuknya yang mirip fathah namun berada di bawah

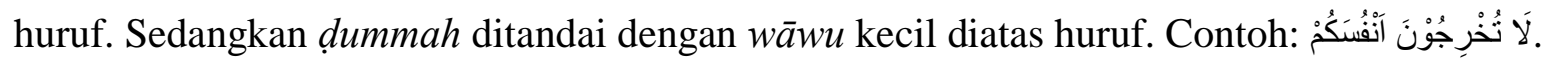

Namun, terkadang penggunaan harakat di dalam naskah berlebihan seperti melebihkan harakat pada lafal al-zakāh yaitu harakat fathạh di atas wāwu (gambar 3)

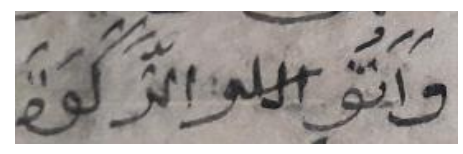

Gambar 3: Penulisan Harakat Yang Berlebihan pada huruf wawu

\section{Sukun}

Tanda sukun dalam naskah H.Habibullah lebih mirip seperti bentuk nūn kecil tanpa titik yang diletakkan terbalik di atas huruf. Namun juga terkadang seperti kepala wāwu kecil di atas huruf. Lihat gambar

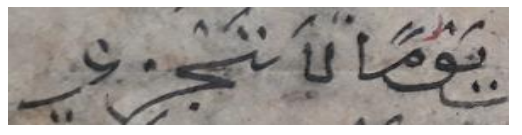

Gambah 4: Penulisan harakat sukun dengan nūn kecil tanpa titik

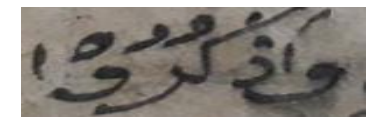

Gambar 5: Penulisan harakat sukun dengan kepala wāwu kecil

Terkadang huruf yang seharusnya diberi tanda sukun namun tidak diberi seperti pada surat al-Baqarah ayat 48(lihat gambar ), Pada lafal شَيَئاً tidak terdapat tanda sukun di atas huruf $y \bar{a}{ }^{\prime}$. 


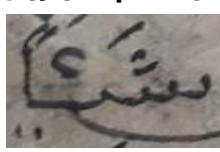

Gambar 6: Tidak diberi harakat sukun yang seharusnya ada

\section{Tanwin}

Penulisan tanda tanwin pada naskah Mushaf al-Qur`an di Madura ini ditandai dengan dua harakat sejajar untuk fathah tanwin dan kasrah tanwin. Tentunya dengan dua harakat fathah sejajar di atas huruf untuk fathah tanwin dan dua harakat kasrah bersejajar di bawah huruf untuk kasrah tanwin. Sedangkan untuk penulisan dhammah tanwin disimbolkan dengan dua huruf $w \bar{a} w u$ kecil yang saling bertentangan atau bertumpuk di atas huruf. Satu huruf $w \bar{a} w u$ menghadap ke atas dan satu huruf lagi terbalik. Sebagaimana gambar berikut:

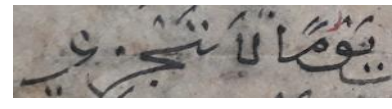

Fathah tanwin

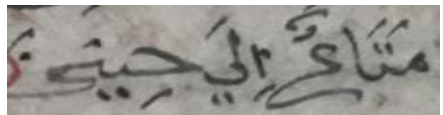

Dhammah tanwin

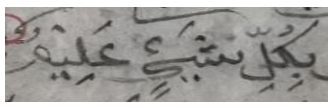

Kasrah tanwin

Bentuk-bentuk tanwin ini tidak ada bentuk khusus pada setiap bacaan sebagaimana yang disebutkan Ghānīm Qaddūrī. Disini penyalin mushaf menetapkan penulisan tanwin sejajar dalam semua tempat. Meskipun huruf setelah tanwin berupa huruf halq atau tidak, atau berupa huruf $b \bar{a}^{\prime}$.

\section{Shiddah}

Shiddah pada manuskip ini disimbolkan dengan kepala huruf shin tanpa titik. Adapun peletakannya tidak ada rumus khusus. Semua huruf yang menyandang shiddah baik berharakat fathah, dhammah atau kasrah tanda shiddahnya diletakkan di atas huruf (Gambar: ). Berbeda dengan rumus yang disampaikan Ghānīm Qaddūrī bahwa terjadi pembedaan tata letak tanda shiddah sesuai harakat yang disandang suatu huruf.

\section{Mād}

Dalam naskah Mushaf al-Qur`an ini penulisan lambang $m \bar{a} d$ tidak disimbolkan dengan tanda tertentu sebagaimana yang dikemukakan oleh Ghānīm Qaddūrī bahwa ada simbolsimbol tertentu yang membedakan antara mād wajib muttaṣil dengan mād jāiz munfaṣil. Simbol $m \bar{a} d$ dalam naskah tidak digunakan atau tidak dikenal dalam penulisan naskah ini. 
Kajian Terhadap Rasm dalam Naskah Mushaf ..... Luluk Asfiatur Rohmah

Doi: doi.org/10.47454/itqan.v4i2.683

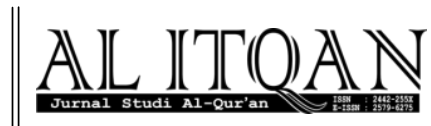

Apabila terdapat suatu kalimat yang dibaca panjang maka ditulis dengan harakat fathah biasa tanpa adanya tanda khusus. Seperti contoh:

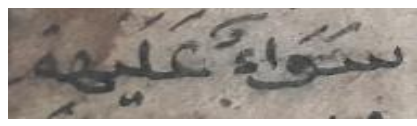

dalam gambar tersebut tidak terdapat tanda khusus untuk lambang $m \bar{a} d$ yang seharusnya berada di atas alif.

\section{Hamzah}

Adapun penulisan hamzah ditulis dengan kepala huruf 'ain dalam versi kecil atau huruf 'ain tanpa tubuh sesuai dengan gagasan al-Khalīl bin Aḥmad al-Farāhidi. Akan tetapi dalam naskah Mushaf al-Qur`an tidak terjadi pembedaan antara simbol hamzah wașal dan hamzah qaț’̄ yang menurut ahli ilmu bahasa Arab tanda hamzah wașal digambarkan dengan kepada $s \bar{a}$.

Inkonsistensi penulisan dalam naskah mushaf al-Qur`an ini dengan mencampurkan antara rasm uthmān̄ dan rasm imla'i disinyalir karena adanya perbedaan kontek sosial, dimana pada masa dahulu belum adanya panduan dan acuan penulisan mushaf al-Qur`andan belum akrab dengan kaidah nahw-sarf sehingga para penulis mushaf hanya mengaktualisasikan hafalan yang dimiliki dengan menuangkannya pada media tulis. Sehingga terjadi inkonsistensi baik dalam satu kaidah atau dalam satu kalimah yang berbeda tempat.

\section{H. Kesimpulan}

Naskah Mushaf al-Qur`an ini berasal dari Desa Konang, Bangkalan, Madura. Naskah ini peninggalan kakek H. Habibullah dan disimpan baik oleh para ahli waris. Dari hasil kajian di atas, penulisan naskah Mushaf al-Qur`an ini koleksi pribadi ahli waris menggunakan rasm campuran antara rasm Uthmānī dan rasm Imla'i, baik dari kaidah pembuangan huruf, penambahan huruf, penulisan hamzah, penggantian huruf dan penulisan tanda baca (harakat), dan juga ada beberapa penulisan yang tidak mengikuti kaidah dua rasm tersebut yakni pada kaidah penambahan alif. Terjadinya inkonsitensi ini dilatarbelakangi oleh belum adanya kaidah acuan penulisan mushaf dan asingnya kaidah nahw-sarf di kalangan muslim Nusantara. 


\section{DAFTAR PUSTAKA}

Dāni, (al) Abu 'Amr 'Uthmān bin Sa'īd. al-Muqni' fì Ma'rifati Marsūm Maṣāḥif Ahli alAmșār. Riyaḍ: Dār al-Tadmuriyyah, 2010.

Ḥamd, (al) Ghānim Qaddūrī. al-Muyassar fì Ilm al-Rasm al-Muṣhaf wa Dabṭihi. Jeddah: Markaz al-Dirāsāt wa al-Ma'lūmāt al-Qur'āniyyāt fị Ma’had al-Imām al-Shāțibīy, 2016.

Madā Imkāniyyah Tauhīd al-Rasm fì Tabā'ah al-Mașāhif.

Turki: Hai’ah Tadqīq al-Maṣahif wa al-Qirāah, 2017.

Hārūn, Abd al-Salam Muḥammad. Qawā'id al-Imlā'. Kediri: Dār al-Mubtadī̄n, th.

Majid, Abu Abduttawab Abdul. Ilmu Rasm dan Dhabth: Seluk Beluk Tanda Baca dalam Mushaf al-Qur'an. ttp: Pustaka Imam Asy-Syafi'i, 2017.

Māraghin̄̄, Ibrāhim bin Aḥmad bin Sulaiman. Dalil al-Hairān 'alā Maurid al-Ẓam'ān. alQahirah: Dār al-Ḥadīth, t.th.

Munawwir,Ahmad Warson. Al-Munawwir Kamus Arab-Indonesia. Surabaya: Pustaka Progresif, 1997.

Najār, (al) Fahmī. Qawā'id al-Imlā' fì 'Ashrah Durūs Sahlah. Riyadh: Mazīdah wa Munqihah, $1429 \mathrm{H}$.

Najikhah, Rif'atun. “Mushaf Menara Kudus Cetakan 1974”. Skipsi, Sekolah Tinggi Agama Islam Al-Anwar Sarang. 2018.

Rahị̄m, (al) 'Abd. Mu’jam al-Mușțalahāt al-Qur'āniyyat. t.tp: tnp, t.th.

Rayyash, Abū 'Abd Tawwab 'Abd Majīd Adawāt al-Dabt al-Qur'ān̄̄ wa Madlūlātuhā, terj. Abu Ya'la Kurnaedi. t.tp: Pustaka Imam Asy-Syafi'i, t.th.

Rayyash, Abū 'Abd Tawwab 'Abd Majīd. Adawāt al-Ḍabt al-Qur'ān̄̄ wa Madlūlātuhā, terj. Abu Ya'la Kurnaedi, t.tp: Pustaka Imam Asy-Syafi'i, t.th.

Sha'roni, Mazmur. Pedoman Umum Penulisan dan Pentashihan Mushaf al-Qur`an Rasm Uthmani. Jakarta: Departemen agama RI: Badan Penelitian dan Pengembangan Agama Puslitbang Lektur, 1999. 

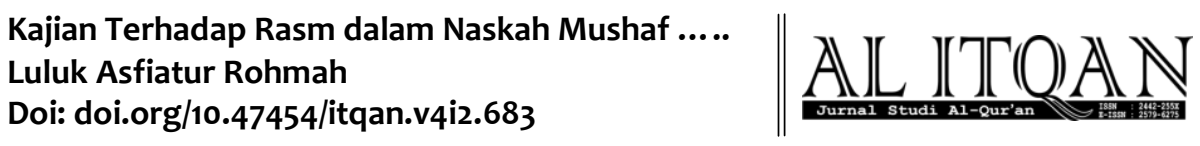

Shalbiy,'Abdul Fattāh Ismā'̄̄l. Rasm al-Mușhaf al-Uthmanī wa Auhāmu al-Mustashriqīn fì qirā'āt al-Qur'ān al-Karīm. t.tp: Maktabah Wahbah, t.th.

Suyūṭị, (al) Abd Raḥmān bin Abī Bakr. al-Itqān fì Ulūm al-Qur'ān. Beirut: Dār al-Kutub al'Ilmiyah, 2018.

Tanasī, (al) Muḥammad bin Abdillah. al-Ṭirraz fì Sharḥi Dabṭ al-Kharrāz. Madīnah: Majma' al-Malik Fahd li Ṭaba'ah al-Muṣḥaf al-Sharīf, 2008.

Zarqānī, Muhammad 'Abd al-'Adẓim. Manāhil al- 'Irfān fì 'Ulūm al-Qur'ān. ttp: Maṭba' Isā al-Bābī al-Ḥalbī wa Syirkāhu, t.th

\section{Wawancara}

Wawancara dengan Abdul Fatah.10 Maret 2018.

Wawancara dengan Abdullah Ahmad Syadzili, wawancara, 28 Maret 2018.

Wawancara dengan Abdullah Ahmad Syadzili. 12 Desember 2018.

Wawancara dengan Abdullah Ahmad Syadzili. 24 Januari 2018. 
Doi: doi.org/10.47454/itqan.v4i2.683 